\title{
VALENCE OF VANADIUM IN HYDRATED COMPOUNDS *
}

\author{
V. Bondarenka ${ }^{\text {a }}$, S. Grebinskij ${ }^{\text {a }}$, S. Mickevičius ${ }^{\text {a }}$, H. Tvardauskas ${ }^{\text {a }}$, S. Kačiulis ${ }^{\text {b }}$, \\ V. Volkov ${ }^{\mathrm{c}}, \mathrm{G}$. Zakharova ${ }^{\mathrm{c}}$, and A. Pašiškevičius ${ }^{\mathrm{a}}$ \\ a Semiconductor Physics Institute, A. Goštauto 11, LT-01108 Vilnius, Lithuania \\ E-mail: bond@pfi.lt \\ ${ }^{\mathrm{b}}$ Institute for the Study of Nanostructured Materials (ISMN-CNR), P.O. Box 10, I-00016 Monterotondo Scalo (RM), Italy \\ E-mail: saulius.kaciulis@mlib.cnr.it \\ ${ }^{\mathrm{c}}$ Institute of Solid State Chemistry, Pervomaiskaya 91, 620219, Yekaterinburg, Russia \\ E-mail: volkov@ihim.uran.ru
}

Received 14 June 2007; revised 2 July 2007

\begin{abstract}
Problems of the definition of vanadium chemical states in the mixed valency compounds are examined. The statistical analysis of the literature data on the values of binding energy and full width at half maximum (FWHM) of V $2 p_{3 / 2}$ peaks in different vanadium oxides is carried out.

$\mathrm{X}$-ray photoelectron spectroscopy was used to determine the chemical shift and FWHM of V $2 p$ peaks of $\mathrm{V}^{4+}$ and $\mathrm{V}^{5+}$ cations in the vanadium pentoxide matrix of hydrated vanadium compounds $\mathrm{HV}_{12} \mathrm{O}_{31} \cdot n \mathrm{H}_{2} \mathrm{O}$ and $(\mathrm{VO}) \mathrm{V}_{12} \mathrm{O}_{31} \cdot n \mathrm{H}_{2} \mathrm{O}$, prepared by using sol-gel technology. It was found that the binding energy of $\mathrm{V}^{4+}$ ions shifts to the lower energy side of about $1.3 \mathrm{eV}$ as compared to the main $\mathrm{V}^{5+}$ ions in the matrix. The $\mathrm{V} 2 p_{3 / 2}$ line width for tetra-valent vanadium ions in xerogels is actually the same as for penta-valent ions.
\end{abstract}

Keywords: sol-gel method, XPS, vanadium oxides

PACS: 81.20.FW, 79.60.-i, 82.80.Pv

\section{Introduction}

The identification of mixed valence metal species in solid oxides is not a trivial task. In fact, chemical analytical methods often fail owing to the relative instability of the various oxidation states of metals in common dissolution media.

Even when they are applicable, long and multi-step procedures have to be scheduled. Moreover, only the bulk concentration of the various species may be extracted, while the investigation of surface chemistry of these compounds is usually required and the surface electronic structure of oxide is also of interest in its own right.

X-ray photoemission spectroscopy (XPS) is a very useful technique for determining such important parameters as the chemical state of different metal species and their relative concentration [1]. By using XPS analysis, species of elements at the surface are identified from XPS spectra, and the oxidation states of the elements are determined from the chemical shift (CS)

\footnotetext{
* The report presented at the 37th Lithuanian National Physics Conference, 11-13 June 2007, Vilnius, Lithuania.
}

defined as the binding energy (BE) difference $\mathrm{CS}_{i j}=$ $\mathrm{BE}_{i}-\mathrm{BE}_{j}$ of the electron concerned ( $i$ and $j$ denote the different valence states). The accurate $\mathrm{BE}$ has to be measured in order to determine the chemical state from the CS. Quantitative information on the relative surface amount of element species then may be obtained from the relative areas of the peaks corresponding to the single components of the envelope spectra. This may be easily done, if the individual peaks are well resolved, i. e. FWHM intensity of the peak is less than the CS for the corresponding species.

\subsection{XPS study of integer valence vanadium oxides}

Vanadium oxides have been intensively studied lately, and the relatively full collection of $\mathrm{V} 2 p_{3 / 2}$ line BE and FWHM data for the main valence oxides $\left(\mathrm{V}_{2} \mathrm{O}_{5}, \mathrm{VO}_{2}\right.$, and $\left.\mathrm{V}_{2} \mathrm{O}_{3}\right)$ may be obtained from the literature analysis.

Unfortunately, the BE values for the various valence vanadium oxides are in a relatively low energy range of about 515.5-517.5 eV [2], while FWHM of the corresponding peaks varies from $1.2 \mathrm{eV}\left(\mathrm{V}_{2} \mathrm{O}_{5}\right.$ [3] $)$ to $3.0 \mathrm{eV}$ 
$\left(\mathrm{NaV}_{2} \mathrm{O}_{5}\right.$ [4]). Moreover, the $\mathrm{CS}$ of $\mathrm{V} 2 p$ peaks for $\mathrm{V}^{3+}$ and $\mathrm{V}^{4+}$ ions from the main valence $\mathrm{V}^{5+}$ is lower than the FWHM of corresponding peaks [5] and the resulting spectra cannot be straightforwardly separated into individual components.

The attempts to fit the $\mathrm{V} 2 p_{3 / 2}$ peak (well resolved from the $\mathrm{V} 2 p_{1 / 2}$ counterpart) in mixed valence vanadium compounds were done with an initially estimated BE separation and the FWHM corresponding to the literature data [6] or directly obtained from the analysis of reference samples XPS spectra [7]. It should be noted, however, that a comparison between $\mathrm{BE}$ and $\mathrm{FWHM}$ data, presented in literature for $\mathrm{V}_{2} \mathrm{O}_{3}, \mathrm{VO}_{2}$, and $\mathrm{V}_{2} \mathrm{O}_{5}$, shows large discrepancies that may be associated either with the equipment calibration or with inaccuracy in the correction for sample charging. Thus, the quantitative estimation of vanadium oxidation states is quite complicated, and the suitable standards for the calibration of BE and FWHM values for $\mathrm{V}^{5+}, \mathrm{V}^{4+}$, and $\mathrm{V}^{3+}$ species in oxides are required. The discrepancies of the reference samples' surface composition from the bulk one may also have influence on the measured values of BE and FWHM. Thus, a statistical review of the data presented in literature is desirable.

\subsection{Literature analysis}

The analysis of literature data on BE and FWHM values of the $\mathrm{V} 2 p_{3 / 2}$ line for the main valence oxides $\left(\mathrm{V}_{2} \mathrm{O}_{5}, \mathrm{VO}_{2}\right.$, and $\left.\mathrm{V}_{2} \mathrm{O}_{3}\right)$ is presented in Table 1 . The statistical methods then may be applied to obtain the mean values of $\mathrm{BE}$ for the corresponding valence vanadium species and to estimate the inaccuracy of the data presented in literature.

The probability that a reported in literature value of parameter $X\left(X\right.$ is $\mathrm{BE}_{i}$ or $\left.\mathrm{CS}_{i j}\right)$ within $X \pm \mathrm{d} X$ interval is given by $2 f_{X} \Delta X$, where $f_{X}$ is the distribution function. The data listed in Table 1 were used to construct the approximate distribution function $f_{X}$ defined as

$$
f_{X}=\frac{\Delta N}{2 N_{\mathrm{t}} \cdot \Delta X},
$$

where $\Delta N$ is the number of references in Table 1 for which $X$ is within $X-\Delta X<X \leq X+\Delta X$ interval (we use $\Delta X=0.2 \mathrm{eV}$ for the convolution of the literature data) and $N_{\mathrm{t}}$ is the total number of corresponding references.

Figure 1 presents the $\mathrm{BE}$ distribution function $f_{\mathrm{BE}}$ for the main valence vanadium oxides. Three fairly well resolved peaks might be seen in Fig. 1, indicating that three different data sets (corresponding to $\mathrm{V}_{2} \mathrm{O}_{5}$,
Table 1. The literature data of FWHM and BE values for $\mathrm{V} 2 p_{3 / 2}$ peak of main valence vanadium oxides.

\begin{tabular}{|c|c|c|c|c|}
\hline \multirow{2}{*}{$\begin{array}{c}\text { FWMH, } \\
\text { eV }\end{array}$} & \multirow{2}{*}{$\begin{array}{l}\mathrm{BE}, \\
\mathrm{eV}\end{array}$} & \multicolumn{3}{|r|}{ Oxide } \\
\hline & & $\mathrm{V}_{2} \mathrm{O}_{3}$ & $\mathrm{~V}_{2} \mathrm{O}_{4}$ & $\mathrm{~V}_{2} \mathrm{O}_{5}$ \\
\hline 4.8 & 515.15 & [8] & & \\
\hline & 515.2 & [9] & & \\
\hline & 515.3 & [10] & & \\
\hline 4.5 & 515.4 & {$[11]$} & & \\
\hline & 515.5 & & [12] & \\
\hline 4.5 & 515.6 & [13] & $\begin{array}{c}{[10,11]} \\
{[11]}\end{array}$ & \\
\hline 4.0 & 515.65 & & [8] & \\
\hline 4.2 & 515.7 & $\begin{array}{c}{[5,14]} \\
{[5]}\end{array}$ & {$[15,16]$} & \\
\hline & 515.8 & [15] & & \\
\hline & 515.85 & [3] & & \\
\hline 1.95 & 516 & & [3] & \\
\hline 3.2 & 516.2 & & [5] & \\
\hline & 516.3 & & {$[14,17]$} & \\
\hline & 516.4 & & [18] & \\
\hline & 516.45 & & [19] & \\
\hline & 516.5 & & [20] & \\
\hline 2.2 & 516.55 & & $\begin{array}{c}{[13,21]} \\
{[21]}\end{array}$ & \\
\hline $\begin{array}{l}2.2 \\
1.6\end{array}$ & 516.6 & & $\begin{array}{l}{[22]} \\
{[22]}\end{array}$ & $\begin{array}{c}{[11,23]} \\
{[23]}\end{array}$ \\
\hline & 516.8 & & & [16] \\
\hline 1.6 & 516.9 & & & $\begin{array}{c}{[5,10]} \\
{[5]}\end{array}$ \\
\hline 1.4 & 517 & & & $\begin{array}{c}{[8,24]} \\
{[8]}\end{array}$ \\
\hline & 517.1 & & & [25] \\
\hline $\begin{array}{l}1.2 \\
1.7 \\
2.0\end{array}$ & 517.2 & & & $\begin{array}{c}{[3,14,18,21,22,26,27]} \\
{[3]} \\
{[21]} \\
{[22]}\end{array}$ \\
\hline & 517.3 & & & [28] \\
\hline & 517.4 & & & {$[20,29-31]$} \\
\hline & 517.45 & & & [19] \\
\hline & 517.6 & & & [13] \\
\hline & 517.65 & & & [32] \\
\hline & 517.7 & & & [32-34] \\
\hline
\end{tabular}




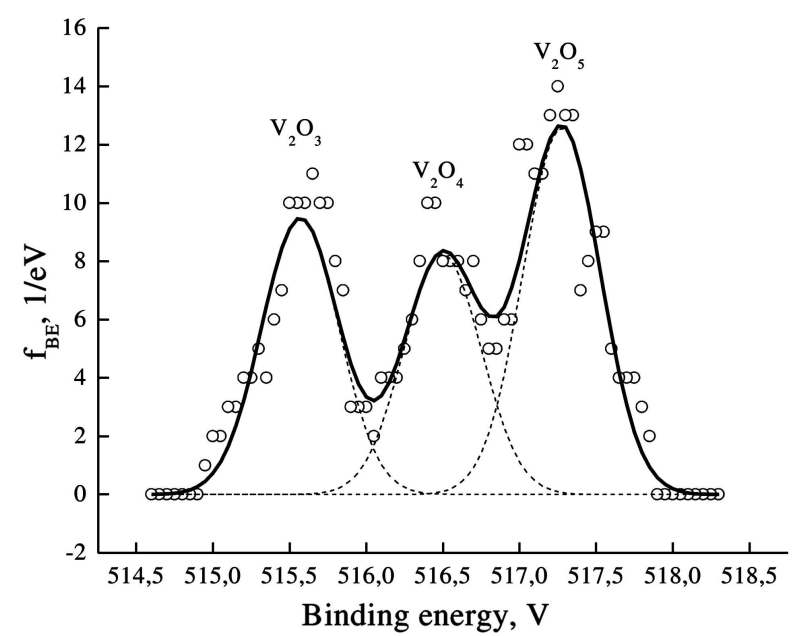

Fig. 1. Distribution function of the $\mathrm{V} 2 p_{3 / 2}$ binding energy values found in the literature for the main valence vanadium oxides. The points correspond to the reference data. The dashed lines present the Gaussian distribution for different oxides, and the solid line is the distribution envelope. Total number of the references $N_{\mathrm{t}}=50$.

$\mathrm{VO}_{2}$, and $\mathrm{V}_{2} \mathrm{O}_{3}$ reference samples) are involved in the distribution function. Further analysis was done assuming that the reference data for individual oxides are distributed according to the Gaussian law:

$$
G_{X}=\frac{\exp \left(-\frac{X-X_{\mathrm{m}}}{2 W_{X}}\right)}{W_{X}(2 \pi)^{1 / 2}},
$$

where $X_{\mathrm{m}}$ is an average value of $X$ and $W_{X}$ is the standard deviation of $X$.

The analysis of $f_{\mathrm{BE}}$ spectrum (Fig. 1) has been performed by using a curve-fitting procedure in order to distinguish vanadium species in different oxidation states and to obtain the corresponding values of $\mathrm{BE}_{\mathrm{m}}$ and $W_{\mathrm{BE}}$.

It is clear from Fig. 1 that $\mathrm{V} 2 p_{3 / 2}$ line BE distribution function may be deconvoluted into three Gaussian peaks centred at 517.3, 516.5, and $515.6 \mathrm{eV}$ with the statistical deviation $W_{\mathrm{BE}}=0.25 \mathrm{eV}$. These peaks may be attributed to $\mathrm{V}^{5+}, \mathrm{V}^{4+}$, and $\mathrm{V}^{3+}$ species in $\mathrm{V}_{2} \mathrm{O}_{5}$, $\mathrm{VO}_{2}$, and $\mathrm{V}_{2} \mathrm{O}_{3}$ oxides respectively. Therefore, it may be concluded that the use of the data reported in literature for the main valence vanadium oxides permits separation of vanadium species in different oxidation states. On the other hand, the statistical error $\delta_{\mathrm{BE}}$ of $\mathrm{BE}$ determination obtained from the literature analysis $\left(\delta_{\mathrm{BE}}=W_{\mathrm{BE}}=0.25 \mathrm{eV}\right.$ and $\delta_{\mathrm{BE}}=2 W_{\mathrm{BE}}=0.5 \mathrm{eV}$ for the $70 \%$ and $95 \%$ probability levels respectively) may be compared with the estimated values of CS for the adjacent valence vanadium oxides $\left(\mathrm{CS}_{34}=-0.9 \mathrm{eV}\right.$ and $\mathrm{CS}_{54}=0.8 \mathrm{eV}$ ). Thus, the accuracy in CS determination from $\mathrm{BE}$ analysis $\left(\delta_{\mathrm{CS}}=2 W_{\mathrm{BE}}=0.5 \mathrm{eV}\right.$ and

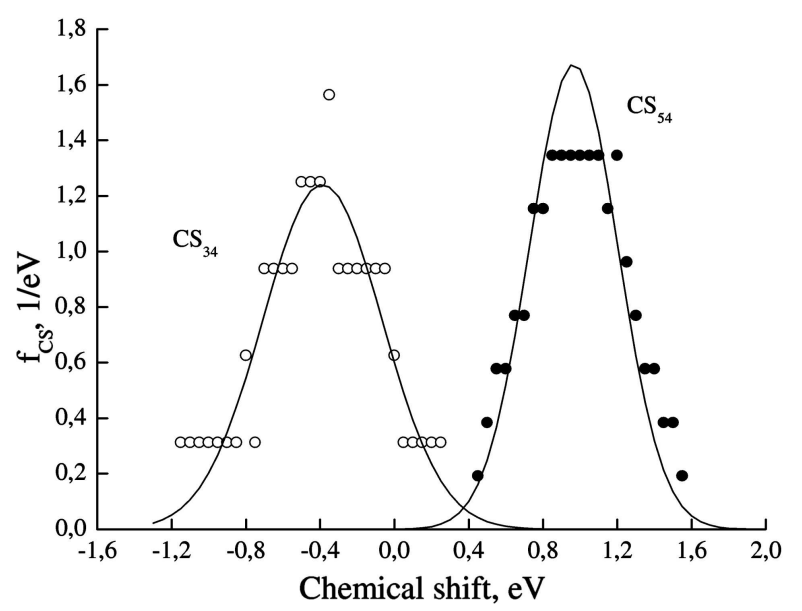

Fig. 2. Distribution function of the V $2 p_{3 / 2}$ chemical shift $\mathrm{CS}_{i j}$ values found in the literature for the main valence vanadium oxides. Open circles correspond to the $\mathrm{V}^{3+}$ and $\mathrm{V}^{4+}$ ions. Bold circles correspond to the $\mathrm{V}^{5+}$ and $\mathrm{V}^{4+}$ ions. Total number of the references for $\mathrm{CS}_{34} N_{\mathrm{t}}=8$ and for $\mathrm{CS}_{54} N_{\mathrm{t}}=13$.

$\delta_{\mathrm{CS}}=4 W_{\mathrm{BE}}=1.0 \mathrm{eV}$ for the $70 \%$ and $95 \%$ probability levels respectively) is insufficient to use these data for the accurate deconvolution of the multicomponent V $2 p_{3 / 2}$ XPS peak envelope. It should be noted that the error in the $\mathrm{V} 2 p_{3 / 2}$ line position determination in vanadium oxides may be compared with the uncertainty (of about $0.3 \mathrm{eV}$ ) of presented in the literature $\mathrm{BE}$ values for the main peaks of $\mathrm{Cu}, \mathrm{Ag}$, and $\mathrm{Au}$, normally used for the equipment calibration [1]. The wide use of $\mathrm{C} 1 s$ level, associated with adventitious carbon as an energy reference in XPS studies, may also contribute to the scattering of the $\mathrm{BE}$ values in vanadium oxides $[8,35]$. On the basis of this background, only the BE data obtained by means of the same equipment employed under the same conditions were used for further statistical analysis of CS in order to minimize the uncertainty related with the equipment calibration and the charge correction procedure. In spite of the relatively low statistics $\left(N_{\mathrm{t}}=8\right.$ for $\mathrm{V}_{2} \mathrm{O}_{3}-\mathrm{VO}_{2}$ and $N_{\mathrm{t}}=$ 13 for $\mathrm{V}_{2} \mathrm{O}_{5}-\mathrm{VO}_{2}$ reference oxides), the $\mathrm{CS}$ analysis is still useful, since not the absolute values but only the $B E$ difference in various valence vanadium oxides with a similar structure and measured at the same conditions is considered.

The results of statistical analysis are presented in Fig. 2. It is evident that either $\mathrm{CS}_{45}$ and $\mathrm{CS}_{43}$ may be approximated by the individual Gaussian distribution ( $X$ in (2) denote CS) with the centres located at -0.4 and $1.0 \mathrm{eV}$ for $\mathrm{CS}_{34}$ and $\mathrm{CS}_{54}$, respectively. These values are in good agreement with the previously obtained results (Fig. 2). However, the uncertainty in the CS determination is relatively high, indicating that the main error in BE determination may be attributed to the 
inaccuracy of the charge correction procedure and to the deviation of the surface composition from the bulk one, rather than to the equipment calibration.

From the literature analysis it may be concluded that:

- the XPS technique permits separation of vanadium species in the adjacent oxidation states;

- the accuracy of BE determination is insufficient for precise deconvolution of the XPS spectra of mixed valence vanadium oxides into individual components;

- the XPS data for the reference samples of vanadium oxides must be interpreted carefully, when they are used for the analysis of mixed valence vanadium compounds.

Moreover, the parameters deduced from the XPS analysis of reference samples may be used only as a rough approximation for those of mixed valence compounds because:

- $\mathrm{CS}_{i j}$ in mixed valence vanadium oxides depends not only on the vanadium ion charge $\mathrm{V}^{+i}$ and $\mathrm{V}^{+j}$, but also on the value of crystal field long-range potential [1]. The last correction may be of the same order of magnitude as the first one;

- in the compounds of transition metal oxides, the FWHM depends on the degree of population of the narrow $d$-band [5], thus the $\mathrm{V} 2 p_{3 / 2}$ line width of $\mathrm{V}^{4+}$ species may differ significantly in $\mathrm{VO}_{2}$ crystals and in $\mathrm{V}_{2} \mathrm{O}_{5}$-based xerogels containing $\mathrm{V}^{4+}$ ions $[5,3]$.

\subsection{The aim of work}

The aim of this work was to determine the chemical shift and FWHM of admixture $\mathrm{V}^{4+}$ ions in the $\mathrm{V}_{2} \mathrm{O}_{5}$ based compounds. It seems that a better way is to compare the samples with the same host matrix, but with different concentrations of reduced valence vanadium ions. In this case, the crystal field is the same for various valence ions, and only the vanadium ions charge affects the CS. The best materials, in our opinion, are the vanadium pentoxide-based hydrated compounds allowing easy intercalation of alkali metal and substitution of vanadium by other transition metals $[36,37]$. This may be done in two different ways:

(1) by a partial substitution of vanadium in $\mathrm{V}_{2} \mathrm{O}_{5}$ based compounds with the transition metal ions of higher or lower valence [38-40] or by using alkali metals $(\mathrm{Na}, \mathrm{K}, \mathrm{Rb}, \mathrm{Cs})[41,42]$ or vanadyl $(\mathrm{VO})^{2+}$ intercalates [43]. In the last case the additional increase of the reduction ratio $\mathrm{RR}=\mathrm{C}_{4} /\left(\mathrm{C}_{4}+\mathrm{C}_{5}\right)$ ( $\mathrm{C}_{i}$ is the atomic concentration of the $i$-valence ion) may be roughly estimated from the nominal chemical formulae, assuming that RR is the same for the basic $\mathrm{V}_{2} \mathrm{O}_{5}$ layers and additional $\mathrm{V}^{4+}$ ions from $(\mathrm{VO})^{2+}$ species;

(2) by varying the concentration of $\mathrm{V}^{4+}$ ions by some external treatment (thermal [44], UV irradiation [45], ion or electron bombardment $[39,46])$ and comparing photoelectron spectra before and after the treatment. The advantage of this technique is that the same sample is used to study the comparison spectra; therefore the structure-related effects may be neglected.

In the present paper we tried to apply these approaches in order to determine the parameters of the $\mathrm{V} 2 p_{3 / 2}$ line in $\mathrm{V}_{2} \mathrm{O}_{5}$-based xerogels. First of all, the reference $\mathrm{V}_{2} \mathrm{O}_{5}$ and $\mathrm{VO}_{2}$ powder oxides were used to determine the $\mathrm{CS}_{54}$ and FWHM in pure oxides. The thin films of $\mathrm{H}_{2} \mathrm{~V}_{12} \mathrm{O}_{31} \cdot n \mathrm{H}_{2} \mathrm{O}$ and $(\mathrm{VO}) \mathrm{V}_{12} \mathrm{O}_{31} \cdot n \mathrm{H}_{2} \mathrm{O}$ xerogels were used for comparison of the materials with a similar structure. Finally, a thin film of $(\mathrm{VO}) \mathrm{V}_{12} \mathrm{O}_{31} \cdot n \mathrm{H}_{2} \mathrm{O}$ xerogel before and after the heat treatment was used to separate the additional influence of $\mathrm{V}^{4+}$ ions on photoelectron spectra.

\section{Experimental}

A polyvanadic acid $\mathrm{H}_{2} \mathrm{~V}_{12} \mathrm{O}_{31} \cdot n \mathrm{H}_{2} \mathrm{O}$ was produced by using the sol-gel technology. The vanadium pentoxide powder was dissolved in hydrogen peroxide at $270 \mathrm{~K}$, because this reaction is exothermic. Then the solution was heated at $350 \mathrm{~K}$ for one hour for the dissociation of the peroxide complexes of vanadium [47].

$(\mathrm{VO}) \mathrm{V}_{12} \mathrm{O}_{31} \cdot n \mathrm{H}_{2} \mathrm{O}$ samples were prepared from $\mathrm{H}_{2} \mathrm{~V}_{12} \mathrm{O}_{31} \cdot n \mathrm{H}_{2} \mathrm{O}$ by using an ionic exchange method. Polyvanadic acid $(0.5 \mathrm{~g})$ was placed in a solution of the vanadyl sulfate $\operatorname{VOSO}_{4} \cdot 3 \mathrm{H}_{2} \mathrm{O}(1 \mathrm{M}, 100 \mathrm{mg})$ and maintained at constant hashing up to balance during 5 days. Then a deposit was filtered, washed out with water, and dried in air at $330 \mathrm{~K}$ [48].

The chemical composition of obtained gels was analysed by IR spectroscopy, chemical, and gravimetrical analysis methods, which showed that the investigated compounds can be described by the formulae $\mathrm{HV}_{12} \mathrm{O}_{31} \cdot n \mathrm{H}_{2} \mathrm{O}$ and (VO) $\mathrm{V}_{12} \mathrm{O}_{31} \cdot n \mathrm{H}_{2} \mathrm{O}$ (more details of the composition determination are described in [49]). The obtained gels were deposited on the Ni substrates and annealed in air at $330 \mathrm{~K}$. 


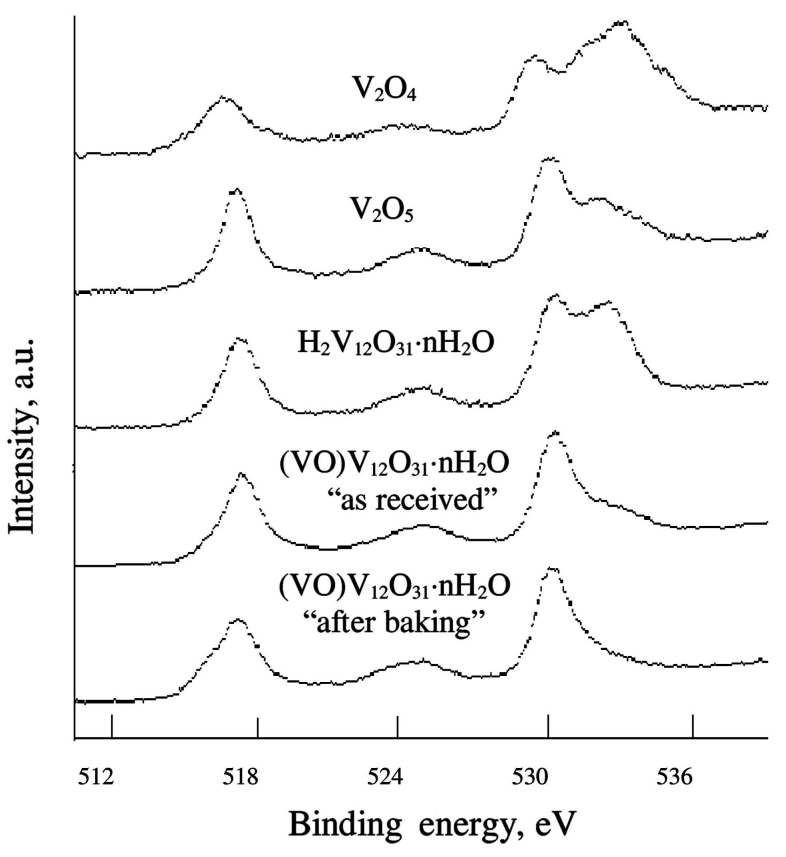

Fig. 3. XPS core-level spectra of V $2 p$ and O $1 s$ region for different samples.

The XPS experiments were carried out in an Escalab MkII (VG Scientific) spectrometer, equipped with an $\mathrm{Al} \mathrm{K}_{\alpha}(1486.6 \mathrm{eV})$ excitation source, a fivechanneltron detection system, and a hemispherical analyzer, which was set to $20 \mathrm{eV}$ pass energy. The binding energy scale was corrected for the charging effect by assigning a value of $284.6 \mathrm{eV}$ to the $\mathrm{C} 1 s$ peak. Photoemission data have been collected and processed by using a VGX-900 data system. After Shirley background subtraction, a nonlinear least square curve-fitting routine has been used for the analysis of XPS spectra.

\section{Results and discussion}

Figure 3 presents the original XPS core-level spectra of the $\mathrm{V} 2 p$ and $\mathrm{O} 1 s$ region for all treated samples. All the spectra have been corrected by removal of X-ray source satellites.

The results and discussion are split into three corresponding regions: core lines of $\mathrm{V} 2 p_{3 / 2}, \mathrm{~V} 2 p_{1 / 2}$, and $\mathrm{O} 1 \mathrm{~s}$.

The preliminary information may be obtained directly from the visual view of the presented spectra. First of all, note, that the spectral lines of the corresponding regions overlap, hence the attempt to analyse each region independently may cause a significant error in the estimations of the areas of related peaks. So, it is necessary to study the whole $\mathrm{V} 2 p$ and $\mathrm{O} 1 s$ region in order to obtain reliable results. On the other hand, $\mathrm{V} 2 p_{3 / 2}$ and $\mathrm{O} 1 s$ lines are considerably separated in

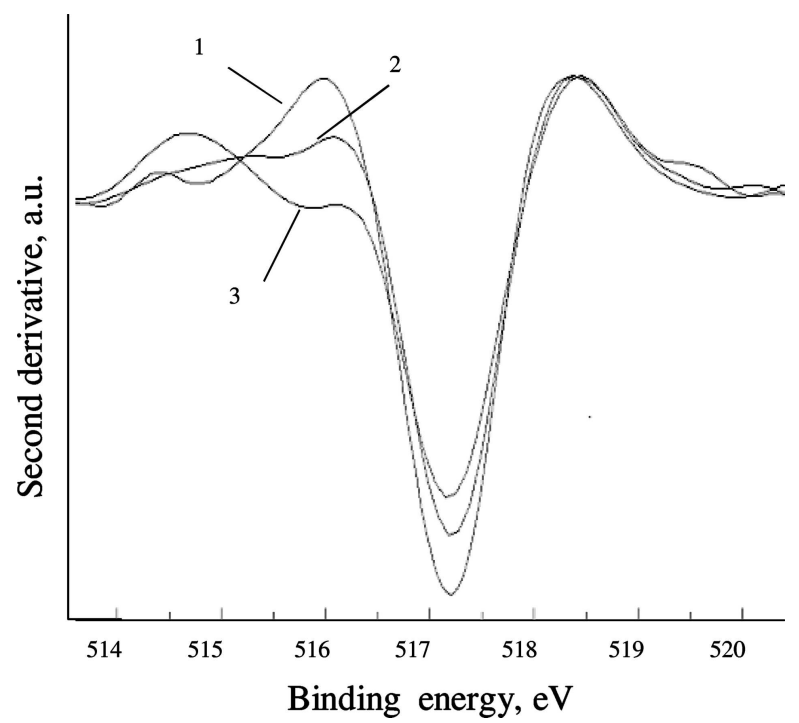

Fig. 4. The second derivatives of XPS spectra for $\mathrm{V}_{2} \mathrm{O}_{5}$-based xerogels: 1 for $\mathrm{H}_{2} \mathrm{~V}_{12} \mathrm{O}_{31} \cdot n \mathrm{H}_{2} \mathrm{O}$ xerogel, 2 for $(\mathrm{VO}) \mathrm{V}_{12} \mathrm{O}_{31} \cdot n \mathrm{H}_{2} \mathrm{O}$ xerogel "as received", 3 for $(\mathrm{VO}) \mathrm{V}_{12} \mathrm{O}_{31} \cdot n \mathrm{H}_{2} \mathrm{O}$ xerogel "after annealing" at $510 \mathrm{~K}$.

$\mathrm{BE}$ scale and the main particularities of corresponding peaks may be revealed by applying the usual methods of the spectra analysis [1].

It is clear that $\mathrm{O} 1 s$ line exhibit a complex structure, indicating that various oxide species are present in the samples. At least three peaks should be introduced to simulate the shape of this line for the studied samples. According to [50], this line may be decomposed into three well-distinguished components: the basic 'oxide' peak, corresponding to vanadium oxide lattice matrix $(\mathrm{BE} \approx 530 \mathrm{eV})$, and two additional peaks arising from $\mathrm{H}_{2} \mathrm{O}(\mathrm{BE} \approx 533 \mathrm{eV})$ and hydrogen or carbon-bonded oxygen 'hydro' species $(\mathrm{BE} \approx 532 \mathrm{eV}$ ) (see Table 2).

Considering the vanadium lines, it may be stated that $\mathrm{V} 2 p_{3 / 2}$ is actually symmetric for $\mathrm{V}_{2} \mathrm{O}_{5}$ and $\mathrm{V}_{2} \mathrm{O}_{4}$ samples, while the obvious widening at the lower $\mathrm{BE}$ shoulder of this spectra may be seen on going from the sample of $\mathrm{H}_{2} \mathrm{~V}_{12} \mathrm{O}_{31} \cdot n \mathrm{H}_{2} \mathrm{O}$ to (VO) $\mathrm{V}_{12} \mathrm{O}_{31} \cdot n \mathrm{H}_{2} \mathrm{O}$ "as received" and to (VO) $\mathrm{V}_{12} \mathrm{O}_{31} \cdot n \mathrm{H}_{2} \mathrm{O}$ annealed at $510 \mathrm{~K}$.

This dependence becomes more evident in the plots of the second derivative (see Fig. 4). For the $\mathrm{H}_{2} \mathrm{~V}_{12} \mathrm{O}_{31}$ $\cdot n \mathrm{H}_{2} \mathrm{O}$ sample, the derivation spectrum is actually symmetric, indicating that $\mathrm{V}^{5+}(\mathrm{BE} \approx 517.2 \mathrm{eV})$ ions dominate in this xerogel. The evident shoulder is, however, seen at $\mathrm{BE} \approx 515.8 \mathrm{eV}$ for the $(\mathrm{VO}) \mathrm{V}_{12} \mathrm{O}_{31} \cdot n \mathrm{H}_{2} \mathrm{O}$ "as received" and "after baking" samples. The appearance of this feature may be attributed to the significant increase of $\mathrm{V}^{4+}$ ions in xerogels after the substitution of $\left(\mathrm{H}_{2}\right)^{2+}$ ions by $(\mathrm{VO})^{2+}$ and the following annealing.

The spectra comparison technique was used for further examination of the core-level states of $\mathrm{V}^{4+}$ ions. 
Table 2. Peak fitting parameters for $\mathrm{O} 1 s$ line.

\begin{tabular}{ccccc}
\hline Sample & Species & BE, eV & FWHM, eV & RA* \\
\hline $\mathrm{H}_{2} \mathrm{~V}_{12} \mathrm{O}_{31} \cdot n \mathrm{H}_{2} \mathrm{O}$ & oxide & 530.1 & 1.7 & 0.47 \\
& "hydro" & 531.9 & 1.7 & 0.32 \\
& $\mathrm{H}_{2} \mathrm{O}$ & 533.0 & 1.7 & 0.21 \\
\hline$(\mathrm{VO}) \mathrm{V}_{12} \mathrm{O}_{31} \cdot n \mathrm{H}_{2} \mathrm{O}$ "as received" & oxide & 530.1 & 1.7 & 0.73 \\
& "hydro" & 531.9 & 1.7 & 0.17 \\
& $\mathrm{H}_{2} \mathrm{O}$ & 533.3 & 1.7 & 0.10 \\
\hline$(\mathrm{VO}) \mathrm{V}_{12} \mathrm{O}_{31} \cdot n \mathrm{H}_{2} \mathrm{O}$ "after baking" & oxide & 530.1 & 1.6 & 0.81 \\
& "hydro" & 531.7 & 1.6 & 0.13 \\
& $\mathrm{H}_{2} \mathrm{O}$ & 533.0 & 1.9 & 0.06 \\
\hline $\mathrm{V}_{2} \mathrm{O}_{5}$ & oxide & 530.1 & 1.8 & 0.49 \\
& "hydro" & 532.2 & 1.8 & 0.26 \\
& $\mathrm{H}_{2} \mathrm{O}$ & 533.9 & 2.4 & 0.26 \\
\hline $\mathrm{V}_{2} \mathrm{O}_{4}$ & oxide & 529.3 & 1.7 & 0.25 \\
& "hydro" & 531.8 & 1.7 & 0.08 \\
& $\mathrm{H}_{2} \mathrm{O}$ & 533.8 & 3.4 & 0.68 \\
\hline
\end{tabular}

${ }^{*}$ RA is relative area of corresponding peaks.

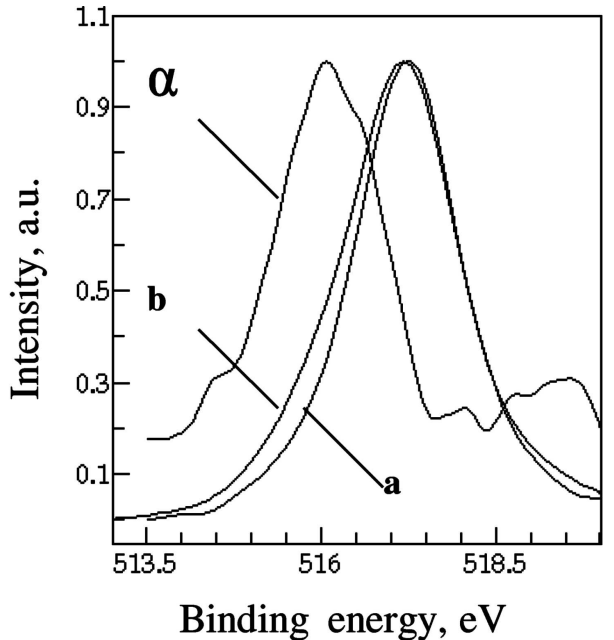

(a)

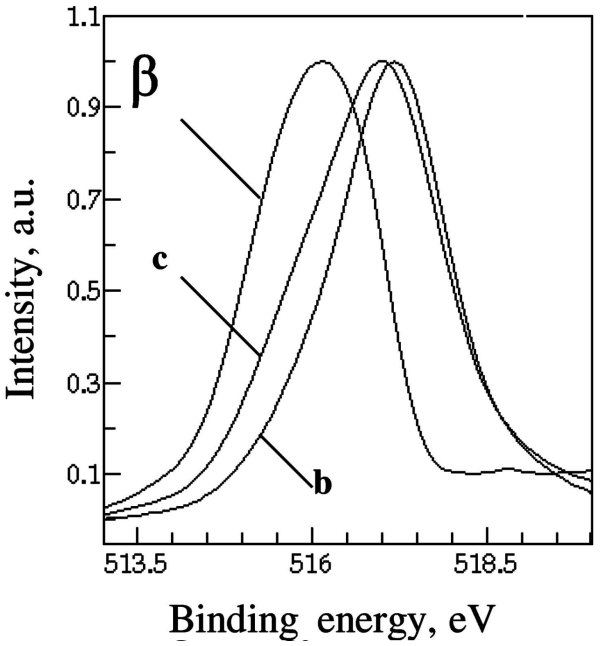

(b)

Fig. 5. The comparison and the difference spectra for $\mathrm{V} 2 p_{3 / 2}$ line in $\mathrm{V}_{2} \mathrm{O}_{5}$-based xerogels: $a$ for $\mathrm{H}_{2} \mathrm{~V}_{12} \mathrm{O}_{31} \cdot n \mathrm{H}_{2} \mathrm{O}, b$ for (VO) $\mathrm{V}_{12} \mathrm{O}_{31} \cdot n \mathrm{H}_{2} \mathrm{O}$ "as received", $c$ for $(\mathrm{VO}) \mathrm{V}_{12} \mathrm{O}_{31} \cdot n \mathrm{H}_{2} \mathrm{O}$ "after annealing" at $510 \mathrm{~K} ; \alpha=b-a \cdot 0.93 ; \beta=c-b \cdot 0.85$.

Figure 5 presents the comparison and the difference spectra for $\mathrm{H}_{2} \mathrm{~V}_{12} \mathrm{O}_{31} \cdot n \mathrm{H}_{2} \mathrm{O}$ and $(\mathrm{VO}) \mathrm{V}_{12} \mathrm{O}_{31} \cdot n \mathrm{H}_{2} \mathrm{O}$ samples, as well as for $(\mathrm{VO}) \mathrm{V}_{12} \mathrm{O}_{31} \cdot n \mathrm{H}_{2} \mathrm{O}$ sample before and after annealing at $510 \mathrm{~K}$.

The optimal weighting procedure was used to extract the low intensity $\mathrm{V}^{4+} 2 p_{3 / 2}$ peak from the high background of the main peak of $\mathrm{V}^{5+} 2 p_{3 / 2}$ [1].

It is clear from Fig. 5(a,b) that the replacement of $\left(\mathrm{H}_{2}\right)^{2+}$ by $(\mathrm{VO})^{2+}$ ions, like the annealing of (VO) $\mathrm{V}_{12} \mathrm{O}_{31} \cdot n \mathrm{H}_{2} \mathrm{O}$ sample, leads to the appearance of an additional peak shifted by $1.1-1.2 \mathrm{eV}$ to the lower energy side. This peak may be attributed to $\mathrm{V}^{4+}$ species and the CS of about $1.2 \mathrm{eV}$ may be expected for $\mathrm{V}^{4+}$ ions in $\mathrm{V}_{2} \mathrm{O}_{5}$-based xerogels that is in a good agreement with a value estimated from the second derivative plots (Fig. 4). Note that this value also agrees with an average $\mathrm{CS}=1.1 \mathrm{eV}$, obtained from the literature analysis.

There are no problems related with the presence of the mixed valence vanadium species in the reference powders of $\mathrm{V}_{2} \mathrm{O}_{5}$ and $\mathrm{V}_{2} \mathrm{O}_{4}$, where the corresponding peak positions and FWHM of $\mathrm{V} 2 p$ and $\mathrm{O} 1 s$ lines can be obtained without any trouble. The peak fitting parameters are given in Tables 2 and 3. The obtained results are in a good agreement with the values reported in Ref. [5].

It should be mentioned that the doublet splitting of V $2 p$ line, obtained from a fitting procedure, is actually 
Table 3. Peak fitting parameters for $\mathrm{V} 2 p_{3 / 2}$ line.

\begin{tabular}{|c|c|c|c|c|c|}
\hline Sample & $\begin{array}{l}\text { Valence of } \\
\text { vanadium }\end{array}$ & $\begin{array}{l}\mathrm{BE}, \\
\mathrm{eV}\end{array}$ & $\begin{array}{c}\text { FWHM, } \\
\text { eV }\end{array}$ & $\begin{array}{l}\text { Reduction } \\
\text { ratio }\end{array}$ & $\begin{array}{c}\text { Chemical } \\
\text { shift }\end{array}$ \\
\hline $\mathrm{H}_{2} \mathrm{~V}_{12} \mathrm{O}_{31} \cdot n \mathrm{H}_{2} \mathrm{O}$ & $\begin{array}{l}5+ \\
4+\end{array}$ & $\begin{array}{l}517.2 \\
515.9\end{array}$ & 1.7 & 0.04 & 1.3 \\
\hline $\begin{array}{c}(\mathrm{VO}) \mathrm{V}_{12} \mathrm{O}_{31} \cdot n \mathrm{H}_{2} \mathrm{O} \\
\text { "as received" }\end{array}$ & $\begin{array}{l}5+ \\
4+\end{array}$ & $\begin{array}{l}517.3 \\
516.0\end{array}$ & 1.6 & 0.13 & 1.3 \\
\hline $\begin{array}{c}(\mathrm{VO}) \mathrm{V}_{12} \mathrm{O}_{31} \cdot n \mathrm{H}_{2} \mathrm{O} \\
\text { "after baking" }\end{array}$ & $\begin{array}{l}5+ \\
4+\end{array}$ & $\begin{array}{l}517.3 \\
516.0\end{array}$ & 1.6 & 0.26 & 1.3 \\
\hline $\mathrm{V}_{2} \mathrm{O}_{5}$ & $5+$ & 517.2 & 1.7 & 0 & 0.6 \\
\hline $\mathrm{V}_{2} \mathrm{O}_{4}$ & $4+$ & 516.6 & 2.2 & 1 & 0.6 \\
\hline
\end{tabular}

the same for all samples (about $7.4 \mathrm{eV}$ ). Also the $\mathrm{V}$ $2 p_{1 / 2}$ and $\mathrm{V} 2 p_{3 / 2}$ peak intensity ratio of 0.5 is in a good agreement with the theoretical value. The peaks of $\mathrm{V} 2 p_{3 / 2}$ are positioned at $\mathrm{BE}=517.2$ and $516.6 \mathrm{eV}$ for $\mathrm{V}_{2} \mathrm{O}_{5}$ and $\mathrm{V}_{2} \mathrm{O}_{4}$ powders, respectively (Table 3). Therefore, the $\mathrm{CS}_{54} \approx 0.6 \mathrm{eV}$, i. e. more than two times lower than the corresponding value for xerogels. This difference may be attributed to the diverse field potential of the surrounding crystal. Moreover, the $\mathrm{V} 2 p_{3 / 2}$ and $\mathrm{V} 2 p_{1 / 2}$ line widths for $\mathrm{V}_{2} \mathrm{O}_{4}$ powder are significantly higher than for $\mathrm{V}_{2} \mathrm{O}_{5}$ reference sample, indicating that the broadening related to the $d$-band population is taking place [5]. So, it may be concluded that the parameters of $\mathrm{V} 2 p$ peaks, deduced from the examination of reference samples, can not be directly used as the initial approximation for the peak-fitting procedure to obtain the accurate value of the reduction ratio of vanadium ions in the xerogels.

The more important conclusion, which may be derived from the comparison plots (Fig. 5), is that the line width of $\mathrm{V} 2 p_{3 / 2}$ peak for tetra-valent vanadium ions in xerogels is actually the same as for penta-valent ions. It seems that this result contradicts the results obtained from the comparison of the photoelectron spectra of reference oxides $\mathrm{V}_{2} \mathrm{O}_{5}$ and $\mathrm{V}_{2} \mathrm{O}_{4}$ (Fig. 3) [5]. Nevertheless, this contradiction may be easily explained, taking into account that the FWHM of the V $2 p$ line in vanadium oxides depends on the degree of completion of the narrow $d$-band [5]. So, in contrast to vanadium tetra- and penta-oxides, with a significantly different concentration of electrons in $d$-band, it is possible to expect the same additional broadening of $\mathrm{V} 2 p$ lines of $\mathrm{V}^{5+}$ and $\mathrm{V}^{4+}$ species, simultaneously present in xerogels with a common $d$-band.

For the further quantitative analysis of the various valence vanadium species in the $\mathrm{V}_{2} \mathrm{O}_{5}$-based xerogels, the peak-fitting procedure has been used. To obtain the position, width, and intensity of spectral components for various vanadium and oxygen species, the photoelectron spectra have been fitted in the whole V $2 p$ and $\mathrm{O} 1 s$ region. According to the previously obtained results, the following initial assumptions about the corresponding peak parameters were done:

- FWHM of V $2 p_{3 / 2}$ and $\mathrm{V} 2 p_{1 / 2}$ peaks is the same for both $\mathrm{V}^{5+}$ and $\mathrm{V}^{4+}$ ions;

- the doublet splitting of $\mathrm{V} 2 p$ line is the same for $\mathrm{V}^{5+}$ and $\mathrm{V}^{4+}$ ions;

- the $\mathrm{V} 2 p_{1 / 2}$ and $\mathrm{V} 2 p_{3 / 2}$ peak intensity ratio is equal to 0.5 for $\mathrm{V}^{5+}$ and $\mathrm{V}^{4+}$ ions.

The fixed value of $\mathrm{CS}=1.3 \mathrm{eV}$ and the abovementioned parameters were used as a starting approximation for the fitting procedure. The $\mathrm{O} 1 s$ peaks corresponding to "oxide", "hydro", and " $\mathrm{H}_{2} \mathrm{O}$ " species position were selected at 530,532, and $533 \mathrm{eV}$, respectively. After that, these parameters were unfixed, and the fitting procedure was repeated.

As an example, a typical deconvolution spectra for "as received" sample of $(\mathrm{VO}) \mathrm{V}_{12} \mathrm{O}_{31} \cdot n \mathrm{H}_{2} \mathrm{O}$, exhibiting the main features related to the simultaneous presence of the $\mathrm{V}^{5+}, \mathrm{V}^{4+}$, "oxide", "hydro", and " $\mathrm{H}_{2} \mathrm{O}$ " species is presented in Fig. 6. The fitting results for all studied samples are listed in Tables 2 and 3.

It should be noted that for $\mathrm{V}^{5+}$ and $\mathrm{V}^{4+}$ ions the $\mathrm{V}$ $2 p_{1 / 2}$ and $\mathrm{V} 2 p_{3 / 2}$ peak intensity ratio for all investigated samples is in the range of $0.50-0.53$, i. e. it is in a good agreement with the value of 0.52 from Scofield's calculations [51]. For a further check, the chemical composition ( $x$ in the chemical formulae $\mathrm{V}_{2} \mathrm{O}_{x}$ ) of the tested samples was derived:

- from the reduction ratio (RR), assuming that only tetra- and penta-valent vanadium is present in the all tested samples. Then $x=5-\mathrm{RR}$; 


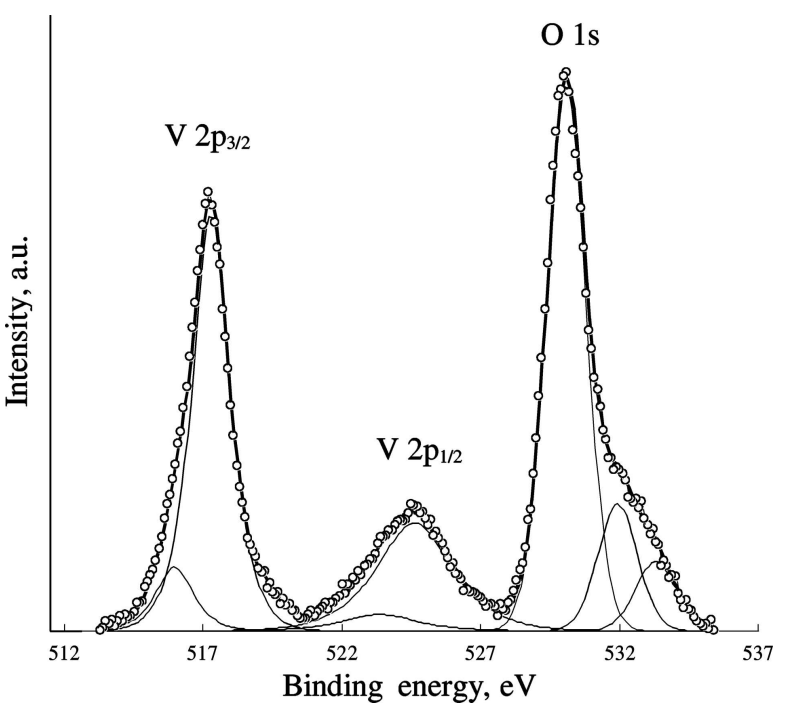

Fig. 6. Fitted X-ray photoelecton spectrum of $\mathrm{V} 2 p$ and $\mathrm{O} 1 s$ region for the "as received" sample of $(\mathrm{VO}) \mathrm{V}_{12} \mathrm{O}_{31} \cdot n \mathrm{H}_{2} \mathrm{O}$ xerogel. Assignment of the spectral components is discussed in the text.

Table 4. Comparison of the chemical compositions of the reference oxides and $\mathrm{V}_{2} \mathrm{O}_{5}$-based xerogels obtained by different methods.

\begin{tabular}{|c|c|c|}
\hline \multirow[t]{2}{*}{ Sample } & \multicolumn{2}{|c|}{$x$ in $\mathrm{V}_{2} \mathrm{O}_{x}$ estimated from: } \\
\hline & reduction ratio & peak intensity \\
\hline $\mathrm{H}_{2} \mathrm{~V}_{12} \mathrm{O}_{31} \cdot n \mathrm{H}_{2} \mathrm{O}$ & 4.96 & 5.00 \\
\hline $\begin{array}{c}(\mathrm{VO}) \mathrm{V}_{12} \mathrm{O}_{31} \cdot n \mathrm{H}_{2} \mathrm{O} \\
\text { "as received" }\end{array}$ & 4.87 & 4.73 \\
\hline $\begin{array}{c}(\mathrm{VO}) \mathrm{V}_{12} \mathrm{O}_{31} \cdot n \mathrm{H}_{2} \mathrm{O} \\
\text { "after baking" }\end{array}$ & 4.74 & 4.64 \\
\hline $\mathrm{V}_{2} \mathrm{O}_{5}$ & 5.00 & 4.91 \\
\hline $\mathrm{V}_{2} \mathrm{O}_{4}$ & 4.00 & 4.15 \\
\hline
\end{tabular}

- from the relative intensities of vanadium and oxygen peaks, assuming that the $\mathrm{O}_{\mathrm{ox}}$ peak corresponds to the basic oxide matrix.

These results are presented in Table 4 .

\section{Conclusions}

The $\mathrm{BE}$ of $\mathrm{V} 2 p_{3 / 2}$ line of $\mathrm{V}^{4+}$ ions in $\mathrm{V}_{2} \mathrm{O}_{5}$-based xerogels is shifted by about $1.3 \mathrm{eV}$ to the lower energy side compared to the basic $\mathrm{V}^{5+}$ line. The chemical shift for pure $\mathrm{V}_{2} \mathrm{O}_{5}$ and $\mathrm{V}_{2} \mathrm{O}_{4}$ oxides is about $0.6 \mathrm{eV}$, i.e. more then two times lower than that obtained for xerogels. This difference may be attributed to the diverse field potential of the surrounding matrix. The peak parameters of the vanadium ions, deduced from the examination of main valence oxides, cannot be directly used for the determination of vanadium valence states in mixed valence compounds.

The $\mathrm{V} 2 p_{3 / 2}$ line width for tetra-valent vanadium ions in xerogels is the same as for penta-valent ions. It contradicts to the results obtained for the pure $\mathrm{V}_{2} \mathrm{O}_{5}$ and $\mathrm{V}_{2} \mathrm{O}_{4}$ oxides where the line widths are different. It may be attributed to the different occupation of the $d$-bands in the mixed valence and stoichiometric vanadium oxides. In contrast to vanadium tetra- and penta-oxides with significantly different concentration of electrons in $d$-band, it is possible to expect the same additional broadening of $\mathrm{V} 2 p$ lines of $\mathrm{V}^{5+}$ and $\mathrm{V}^{4+}$ species present in xerogels with a common $d$-band.

The substitution of the hydrogen ions by the vanadyl (VO) groups in the $\mathrm{V}_{2} \mathrm{O}_{5}$-based xerogels leads to the significant increase of the $\mathrm{V}^{4+}$ ions concentration in these compounds. A similar increase was observed when the samples were annealed in vacuum, where it may be related to the preferential removal of oxygen from the host layers of the vanadium oxide.

\section{Acknowledgement}

This work was partly supported by Agency for International Science and Technology Development in Lithuania, Grant No. 10V-125 within the frame of COST D35.

\section{References}

[1] S. Briggs and M.P. Seah, Practical Surface Analysis, Vol. 1 (Wiley, New York, 1990).

[2] J.F. Moulder, W.F. Stricle, P.E. Sobol, and K.D. Bomben, Handbook of X-Ray Photoelectron Spectroscopy (Perkin-Elmer Corporation, Physical Electronics Division, 1995).

[3] M. Demeter, M. Neumann, and W. Reichelt, Mixedvalence vanadium oxides studied by XPS, Surf. Sci. 454-456(18), 41-44 (2000).

[4] V. Bondarenka, Z. Martunas, S. Kaciulis, and L. Pandolfi, Sol-gel synthesis and XPS characterization of sodium-vanadium oxide bronze thin films, J. Electron Spectrosc. Related Phenom. 131-132(1), 99-103 (2003).

[5] G.A. Sawatzky and D. Post, X-ray photoelectron and Auger spectroscopy study of some vanadium oxides, Phys. Rev. B 20(4), 1546-1555 (1979).

[6] C. Malitesta, L. Sabbatini, L. Torsi, P.G. Zambonin, D. Ballivet-Tkatchenko, J. Galy, J.-L. Parize, and J.M. Savariault, Copper speciation by analytical electron spectroscopies: Case of the intercalation phase $\mathrm{Cu}_{0.5} \mathrm{~V}_{2} \mathrm{O}_{5} \cdot 0.5 \mathrm{H}_{2} \mathrm{O}$, Surf. Interf. Analysis 19(1-12), 513-518 (1992). 
[7] M.P. Casaletto, L. Lisi, G. Mattogno, P. Patrono, G. Ruoppolo, and G. Russo, Oxidative dehydrogenation of ethane on $\gamma-\mathrm{Al}_{2} \mathrm{O}_{3}$ supported vanadyl and iron vanadyl phosphates: Physico-chemical characterisation and catalytic activity, Appl. Catalysis A 226(1-2), 41-48 (2002).

[8] J. Medialdua, R. Casanova, and Y. Barbaux, XPS studies of $\mathrm{V}_{2} \mathrm{O}_{5}, \mathrm{~V}_{6} \mathrm{O}_{13}, \mathrm{VO}_{2}$ and $\mathrm{V}_{2} \mathrm{O}_{3}$, J. Electron Spectrosc. Related Phenom. 71(3), 249-261 (1995).

[9] Z. Zhang and V.E. Henrich, Electronic interactions in the vanadium $/ \mathrm{TiO}_{2}(110)$ and vanadia $/ \mathrm{TiO}_{2}(110)$ model catalyst systems, Surf. Sci. 277(3), 263-272 (1992).

[10] G. Hopfengartner, D. Borgmann, I. Rademacher, G. Wedler, E. Hums, and G.W. Spitznagel, XPS studies of oxidic model catalysts: Internal standards and oxidation numbers, J. Electron Spectrosc. Related Phenom. 63(2), 91-116 (1993).

[11] S.L.T. Andersson, ESCA investigation of $\mathrm{V}_{2} \mathrm{O}_{5}+\mathrm{TiO}_{2}$ catalysts for the vapour phase oxidation of alkylpyridines, J. Chem. Soc. Faraday Trans. I 75, 1356-1370 (1979).

[12] J. Cui, D. Da, and W. Jiang, Structure characterization of vanadium oxide thin films prepared by magnetron sputtering methods, Appl. Surf. Sci. 133(3), 225-229 (1998).

[13] R. Holm and S. Storp, ESCA studies of chemical shifts for metal oxides, Appl. Phys. A 9(3), 217-222 (1976).

[14] R.J. Colton, A.M. Guzman, and J.W. Rabalais, Electrochromism in some thin-film transition-metal oxides characterized by x-ray electron spectroscopy, J. Appl. Phys. 49(1), 409-416 (1978).

[15] B. Horvath, J. Strutz, J. Geyer-Lippmann, and E.G. Horvath, Preparation, properties, and ESCA characterization of vanadium surface compounds on silicagel. II, Z. Anorg. Allg. Chem. 483(12), 193-204 (1981).

[16] G. Blaauw, F. Leenhouts, F. van der Woude, and G.A. Sawatsky, The metal-non-metal transition in $\mathrm{VO}_{2}$ : X-ray photoemission and resistivity measurements, J. Phys. C 8(4), 459-468 (1975).

[17] J. Kasperkiewicz, J.A. Kovacich, and D. Lichtman, XPS studies of vanadium and vanadium oxides, J. Electron Spectrosc. Related Phenom. 32(2), 123132 (1983).

[18] V. Bondarenka, S. Grebinskij, S. Kačiulis, G. Mattogno, and S. Mickevičius, Surface chemical composition of $\mathrm{MV}_{10} \mathrm{Mo}_{2} \mathrm{O}_{31} \cdot n \mathrm{H}_{2} \mathrm{O}\left(\mathrm{M}=\mathrm{Na}_{2}, \mathrm{~K}_{2}, \mathrm{Ca}, \mathrm{Sr}\right.$, $\mathrm{Cu})$ xerogels, J. Electron Spectrosc. Related Phenom. 107(3), 253-259 (2000).

[19] S. Lu, L. Hou, and F. Gan, Preparation and optical properties of phase-change VO[2] thin films, J. Mater. Sci. 28(8), 2169-2177 (1993).

[20] A.I. Minyaev, I.A. Denisov, V.E. Soroko, and V.A. Konovalov, Study of solid phase transformation of vanadium based systems, Zh. Prikl. Khim. [Russ. J. Appl. Chem.] 59(2), 339-343 (1986).

[21] Present paper.

[22] M.P. Casaletto, S. Kaciulis, L. Lisi, G. Mattogno, A. Mezzi, P. Patrono, and G. Ruoppolo, XPS characterisation of iron-modified vanadyl phosphate catalysts, Appl. Catalysis A 218(1-2), 129-137 (2001).

[23] R. Larsson, B. Folkesson, and G. Schoen, X-ray photoelectron spectroscopy and homogenous catalysis. 1 . Investigations on some vanadium compounds, Chem. Scr. 3(2), 88-90 (1973).

[24] B. Barbaray, J.P. Contour, and G. Mouvier, Effects of nitrogen dioxide and water vapour on oxidation of sulphur dioxide over vanadium pentoxide particles, Env. Sci. Technol. 12(12), 1294-1297 (1978).

[25] M. Takagi-Kawai, M. Soma, T. Onishi, and K. Tamaru, The adsorption and the reaction of $\mathrm{NH}_{3}$ and $\mathrm{NO}_{x}$ on supported $\mathrm{V}_{2} \mathrm{O}_{5}$ catalysts: Effect of supporting materials, Canadian J. Chem. 58(20), 2132-2137 (1980).

[26] W.E. Slinkard and P.B. Degroot, Vanadium-titanium oxide catalysts for oxidation of butene to acetic acid, J. Catalysis 68(2), 423-432 (1981).

[27] Z. Zhang and V.E. Henrich, Surface electronic structure of $\mathrm{V}_{2} \mathrm{O}_{5}(001)$ : Defect states and chemisorption, Surf. Sci. 321(1-2), 133-144 (1994).

[28] J.L.G. Fierro, L.A. Arrua, J.M.L. Nieto, and G. Kremenic, Surface properties of co-precipitated V-Ti-O catalysts and their relation to the selective oxidation of isobutene, Appl. Catalysis 37(1-2), 323-338 (1988).

[29] A. Meisel, K.H. Hallmeier, R. Szargan, J. Muller, and W. Schneider, Investigation of soft $\mathrm{X}$-ray emission and K-edge absorption spectra of $\mathrm{V}_{2} \mathrm{O}_{5}$ and $\mathrm{Li}_{x} \mathrm{~V}_{2} \mathrm{O}_{5}$ electrodes, Phys. Scripta 41(4), 513-516 (1990).

[30] V.I. Nefedov, Y.V. Salyn, G. Leonhardt, and R. Scheibe, A comparison of different spectrometers and charge corrections used in X-ray photoelectron spectroscopy, J. Electron Spectrosc. Related Phenom. 10(2), 121-124 (1977).

[31] Y. Schuhl, H. Baussart, R. Delobel, M. Le Bras, J. Leroy, L.G. Gengembre, and J. Rimblot, Study of mixed-oxide catalysts containing bismuth, vanadium and antimony. Preparation, phase composition, spectroscopic characterization and catalytic oxidation of propene, J. Chem. Soc. Faraday Trans. I 79(9), 20552069 (1983).

[32] C.D. Wagner, W.M. Riggs, L.E. Davis, J.F. Moulder, and G.E. Muilenberg, Handbook of X-Ray Photoelectron Spectroscopy (Perkin-Elmer Corporation, Physical Electronics Division, 1979).

[33] F.J. Berry, M.E. Brett, R.A. Marbrow, and W.R. Patterson, An X-ray photoelectron spectroscopic study of the surface properties of vanadium antimonate and $\beta$-antimony tetroxide, J. Chem. Soc. Dalton Trans., No. 5, 985-987 (1984).

[34] V.I. Nefedov, M.N. Firsov, and I.S. Shaplygin, Electronic structures of $\mathrm{MRhO}_{2}, \mathrm{MRh}_{2} \mathrm{O}_{4}, \mathrm{RhMO}_{4}$ and 
$\mathrm{Rh}_{2} \mathrm{MO}_{6}$ on the basis of X-ray spectroscopy and ESCA data, J. Electron Spectrosc. Related Phenom. 26(1), 65-78 (1982).

[35] S. Hashimoto, K. Hirokawa, Y. Fukuda, K. Suzuki, T. Suzuki, N. Usuki, N. Gennai, S. Yoshida, M. Koda, H. Sezaki, H. Horie, A. Tanaka, and T. Ohtsubo, Correction of peak shift and classification of change of $\mathrm{X}$-ray photoelectron spectra of oxides as a result of ion sputtering, Surf. Interf. Analysis 18(12), 799-806 (1992).

[36] J. Bullot, P. Cordier, O. Gallais, M. Gauthier, and J. Livage, Thin layers deposited from $\mathrm{V}_{2} \mathrm{O}_{5}$ gels : I. A conductivity study, J. Non-Cryst. Solids 68(1), 123-134 (1984).

[37] J. Livage, Synthesis of polyoxovanadates via "chimie douce", Coordination Chem. Rev. 178-180(2), 9991018 (1998).

[38] V. Bondarenko, S. Kaciulis, A. Plesanovas, V. Volkov, and G. Zacharova, Photoelectron spectroscopy of the poly-vanadium transition metal acids, Appl. Surf. Sci. 78(1), 107-112 (1994).

[39] V. Bondarenka, H. Tvardauskas, S. Grebinskij, S. Mickevicius, Z. Martunas, V. Volkov, and G. Zakharova, Ion beam induced preferential removal of oxygen from vanadium hydrates, Nucl. Instrum. Methods B 178(1-4), 323-326 (2001).

[40] V. Bondarenka, S. Grebinskij, S. Mickevičius, H. Tvardauskas, Z. Martūnas, V. Volkov, and G. Zakharova, Humidity sensors based on $\mathrm{H}_{2} \mathrm{~V}_{11} \mathrm{TiO}_{30.3} \cdot n \mathrm{H}_{2} \mathrm{O}$ xerogels, Sensors Actuators B 55(1), 60-64 (1999).

[41] T. Yao, Y. Oka, and N. Yamamoto, Layered structures of hydrated vanadium oxides. Part 1. - Alkali-metal intercalates $\mathrm{A}_{0.3} \mathrm{~V}_{2} \mathrm{O}_{5} \cdot n \mathrm{H}_{2} \mathrm{O}(\mathrm{A}=\mathrm{Na}, \mathrm{K}, \mathrm{Rb}, \mathrm{Cs}$ and $\mathrm{NH}_{4}$ ), J. Mater. Chem. 2(3), 331-336 (1992).

[42] V. Bondarenka, S. Mickevičius, H. Tvardauskas, S. Grebinskij, S. Kačiulis, G. Mattogno, V. Volkov, and G. Zakharova, X-ray photoelectron spectroscopy of $\mathrm{NaxV}_{2} \mathrm{O}_{5}(\beta)$ bronze, Lithuanian J. Phys. 40(5), 353-355 (2000).

[43] T. Yao, Y. Oka, and N. Yamamoto, Layered structures of hydrated vanadium oxides. Part 2. - Vanadyl intercalates (VO) $)_{x} \mathrm{~V}_{2} \mathrm{O}_{5} \cdot n \mathrm{H}_{2} \mathrm{O}$, J. Mater. Chem. 2(3), 337340 (1992).

[44] S. Mickevičius, V. Bondarenka, S. Grebinskij, S. Kačiulis, H. Tvardauskas, and Z. Martūnas, The study of dehydration of $\mathrm{H}_{2} \mathrm{~V}_{11.5} \mathrm{Cr}_{0.5} \mathrm{O}_{31} \cdot n \mathrm{H}_{2} \mathrm{O}$ xerogel by XPS and TDS, Lithuanian J. Phys. 42(2), 127-130 (2002).

[45] V. Bondarenka, Z. Martūnas, S. Kačiulis, L. Pandolfi, S. Grebinskij, and S. Mickevičius, Influence of UV radiation on the vanadium ions in vanadium hydrates, Lithuanian J. Phys. 42(4), 281-284 (2002).

[46] V. Bondarenka, Sol-gel technology: Vanadium compounds, in: Proceedings of Conference 'Lithuanian Science and Industry; Applied Physics' (Kaunas, Lithuania, 2004) pp. 29-30.

[47] V.L. Volkov, G.S. Zakharova, and A.A. Ivakin, Synthesis and properties of hydrated polyvanadomolybdic acid, Zh. Neorg. Khim. [Russian J. Inorg. Chem.] 30(3), 642-645 (1985).

[48] G.S. Zakharova and V.L. Volkov, Intercalation compounds based on vanadium oxide (V) xerogel, Usp. Khim. [Russ. Adv. Chem.] 72(4), 346-362 (2003).

[49] V.L. Volkov, G.S. Zakharova, and V. Bondarenka, Xerogels of Simple and Modificated Polyvanadates (Ural Branch of the Russian Academy of Sciences, Yekaterinburg, 2001) [in Russian].

[50] N. Soga and M. Senna, Change in the dehydration and crystallization processes of $\mathrm{V}_{2} \mathrm{O}_{5}$ xerogel due to mechanical pretreatment, J. Solid State Chem. 107(1), 159-165 (1993).

[51] J.H. Scofield, Hartree-Slater subshell photoionization cross-sections at 1254 and $1487 \mathrm{eV}$, J. Electron Spectrosc. Related Phenom. 8(2), 129-137 (1976).

\title{
VANADŽIO VALENTINGUMAS HIDRATUOTUOSE JUNGINIUOSE
}

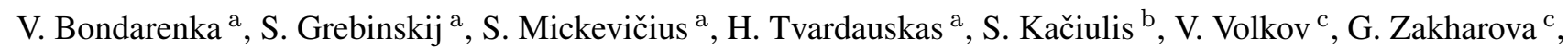 \\ A. Pašiškevičius a \\ ${ }^{a}$ Puslaidininkiu fizikos institutas, Vilnius, Lietuva \\ ${ }^{\mathrm{b}}$ Nanostruktūriniu medžiagu tyrimo institutas, Roma, Italija \\ ${ }^{\mathrm{c}}$ Kietojo kūno chemijos institutas, Jekaterinburgas, Rusija
}

\section{Santrauka}

Analizuojama cheminė daugiavalenčių vanadžio junginių sandara. Atlikta V $2 p_{3 / 2}$ smailių ryšio energijos ir ju puspločio įvairiuose vanadžio oksiduose literatūrinių duomenų statistinė analizè.

Rentgeno fotoelektronu spektroskopijos (RFS) metodu buvo tirti hidratuoti vanadžio pentoksido $\mathrm{HV}_{12} \mathrm{O}_{31} \cdot n \mathrm{H}_{2} \mathrm{O}$ ir $(\mathrm{VO}) \mathrm{V}_{12} \mathrm{O}_{31}$
\end{abstract}

$\cdot n \mathrm{H}_{2} \mathrm{O}$ bandiniai, pagaminti taikant standartinę zolio ir gelio technologiją. Nustatyta, kad $\mathrm{V}^{4+}$ jonų ryšio energija (RE), lyginant su pagrindinių matricos $\mathrm{V}^{5+}$ jonų $\mathrm{RE}$, pasislinkusi i mažesnių energijos verčių pusę maždaug per $1,3 \mathrm{eV}$, o abieju jonų smailių puspločiai yra vienodi. 